- long enough to overlap with at least some of the Sentinels, allowing for cross-calibrations of instruments and continuous data-taking. "Continuity for a climate record is extremely important," says Fred Prata, a climate scientist at the Norwegian Institute for Air Research in Kjeller. Given Envisat's troubles, he says, "Europe should really be fast-tracking ESA's Sentinel programme".

But the European Commission does not want to allocate $€ 5.8$ billion of its 2014-20 budget to the programme that would operate the satellites, the Global Monitoring for Environment and Security (GMES). Instead, the commission says, member states should make additional contributions to finance the programme - something that is unlikely to happen in the current fiscal climate (see Nature 480, 19-20; 2011). ESA, meanwhile, says that it will not launch the first Sentinel without being certain that its operating costs will be covered.

Volker Liebig, director of ESA's Earthobserving programme, accuses the commission of using GMES as a bargaining chip in broader budget negotiations. "They are taking this as a tactical hostage to get more money from the member states," he says. Carlo Corazza, a spokesman for the commission, denies this, insisting that his organization is only trying to ensure that the GMES programme receives adequate funding.

With the negotiations dragging on, Liebig says that he is running out of time to make arrangements with the French spaceflight company Ariannespace in Evry-Courcouronnes, which will provide the rocket to launch Sentinel 1. That deal must be in place by June if the satellite is to fly by mid-2013. Corazza says that discussions are continuing fast enough to keep Sentinel on track.

Not everyone believes that the situation poses a significant problem for Earth observation. Other satellites, such as NASA's Aqua and Terra missions, can replace Envisat's capabilities, says Ranga Myneni, an environmental scientist at Boston University in Massachusetts. Indeed, satellites launched by NASA freely provide their data in formats preferred by many scientists, and are thus more widely used than Envisat.

But Envisat had some functions that cannot be replaced. In addition to its ability to measure $\mathrm{CO}_{2}$, the satellite's Advanced Along
Track Scanning Radiometer was, Prata says, the world's best instrument for measuring sea surface temperatures. It was also part of a $€ 2$-million project to improve the forecasting of volcanic ash clouds, such as the one that belched from Eyjafjallajökull in Iceland and disrupted transatlantic air traffic in 2010. The failure - together with the gap in observations - means that the project will have to look to NASA instruments instead.

Michel Verstraete, a climate scientist at the European Commission's Joint Research Centre in Ispra, Italy, points out that Envisat's synthetic aperture radar was particularly good at spotting standing water, even under heavy cloud cover. "If tomorrow there is a flood, people will ask, 'Where are the data?"' he says. Europe needs its own robust capabilities to monitor weather and crops, Prata adds. "If you have control of your own satellites, you don't have to ask your friends or your enemies," he says.

With a financial impasse on one side and a moribund satellite on the other, researchers are left with few options, Burrows says. "We're praying that Envisat might come back. I'm going to church again."

\title{
GENOMICS
}

\section{A bloody boon for conservation}

\section{Leeches provide traces of DNA from other species.}

\section{BY EWEN CALLAWAY}

$\mathrm{B}$ loodsucking leeches are offering the best hope of finding one of the world's rarest animals. The saola (Pseudoryx nghetinhensis) was first described from skulls found in a Vietnamese forest reserve ${ }^{1}$, but the elusive antelope has rarely been seen alive. Little is known about its range or population, which probably numbers in the low hundreds.

Conservationists are now planning to trawl tropical leeches for saola DNA. Prompted by research published this week ${ }^{2}$ showing that the bloodsuckers can store DNA from their meals for several months, the saola search is at the vanguard of an approach to gauging biodiversity that could prove much more efficient than conventional methods. Rather than setting out camera traps, the idea is to collect and sequence DNA left in the environment, in everything from soil to leeches' stomachs.

"I am almost sure that in ten years all the research on biodiversity will be done with
DNA, because it will be so easy to get this type of information and the cost is not very high," says Pierre Taberlet, a geneticist at Joseph Fourier University in Grenoble, France, and co-editor of the April issue of Molecular Ecology, which is devoted to the emerging field of

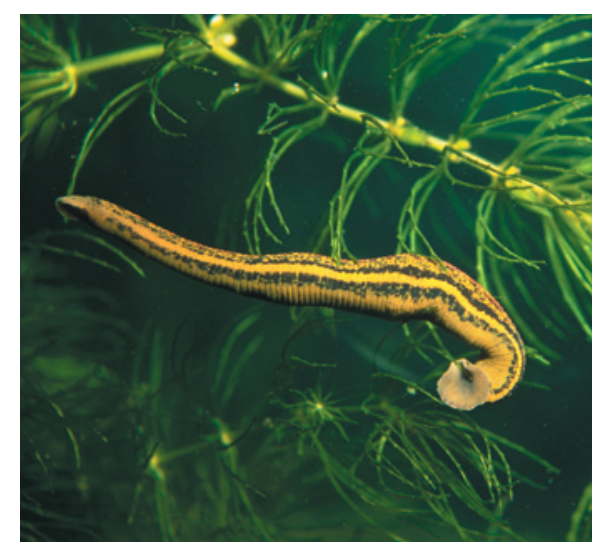

Bloodsuckers feast on the forest's rare delicacies. studying environmental DNA.

The saola is so elusive that it has been dubbed the Asian unicorn. It hadn't been spotted for a decade until 2010, when villagers in the Laotian province of Bolikhamxay caught one alive, only for the animal to die after a few days in captivity.

In 2011, Vietnam established a small saola reserve in the animal's only known habitat, the Annamite mountains that straddle the country's border with Laos. A more precise estimate of the antelope's range would help to target conservation efforts, says Nicholas Wilkinson, a Vietnam-based wildlife ecologist at the University of Cambridge, UK, who is working with the conservation group WWF. Their team failed to find the saola using camera traps and considered bringing in trained dogs to help the hunt, at an estimated cost of US $\$ 400,000$. "I, to a large extent, had given up on finding a survey method that would be useful in time to save the species," Wilkinson says.

But last year, he received an e-mail from geneticist Thomas Gilbert at the University of Copenhagen, describing his experiments with leeches. Gilbert, his colleague Mads Bertelsen and their team had fed goat blood to medicinal leeches (Hirudo spp.) - something that is "a lot harder than it sounds", says Gilbert. The team resorted to tempting the creatures with blood-filled condoms warmed under a heatlamp, and putting the leeches into syringes attached to blood-filled test tubes sealed by a thin film. After killing the leeches over the course of several months, the team identified goat DNA in every one of them. 


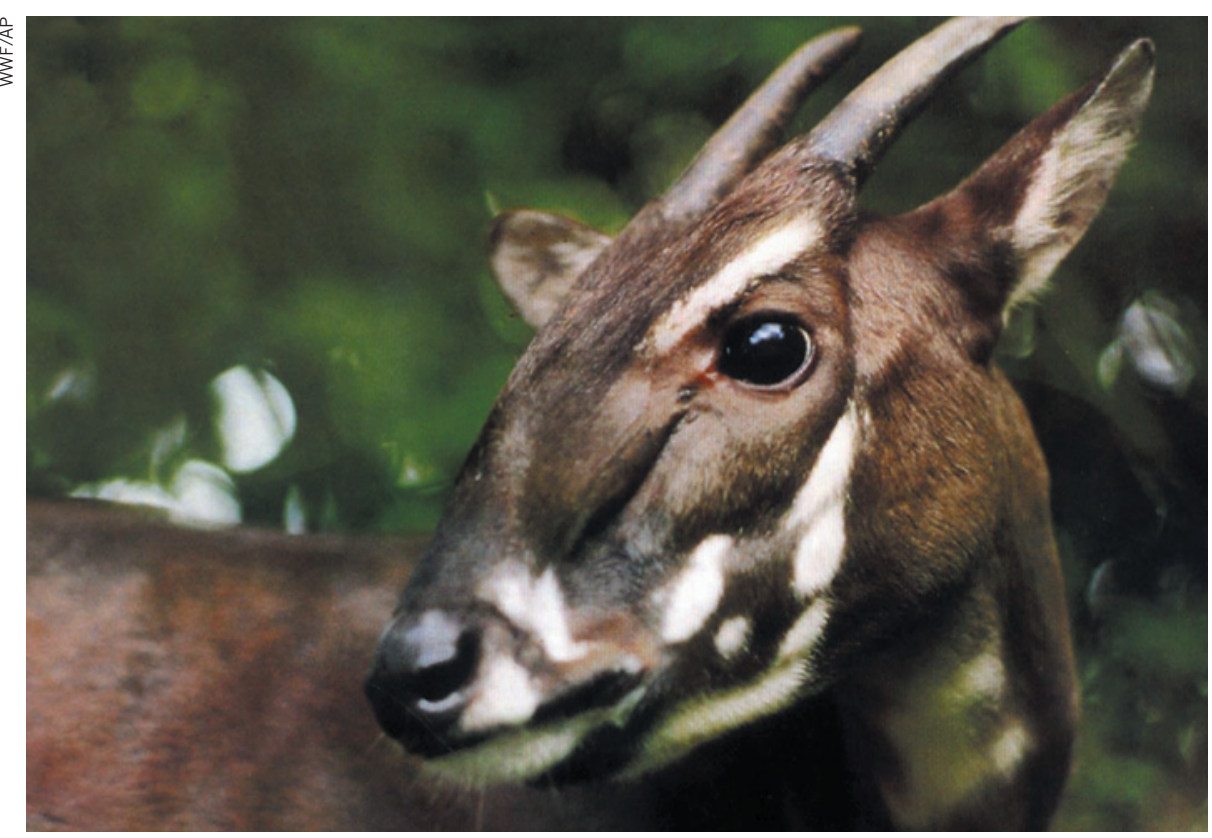

Scientists hope to find DNA from the rare saola in leeches from the antelope's expected range.

To see whether the technique could find mammal DNA in the wild, Gilbert asked Wilkinson to ship him some tropical leeches (Haemadipsa spp.). Wilkinson collected them on the Vietnamese side of the Annamite Range and sent them to Copenhagen. Gilbert's team did not find any saola DNA, but 21 of the 25 leeches they tested contained DNA from other mammals, including the Truong Son muntjac deer (Muntiacus truongsonensis) and the Annamite striped rabbit (Nesolagus timinsi), which was discovered only a decade ago. The International Union for Conservation of Nature (IUCN) lists both species as 'data deficient' because scientists know so little about their populations or habitat.

"It is a very easy way to get a snapshot of what animals are in the area," says Gilbert. Leeches are impossible to avoid in tropical forests, and they can be collected by the dozen by simply peeling them off intrepid researchers' clothes. The plummeting cost of DNA sequencing makes leech surveys cheap, and DNA from hundreds of the animals could be combined and analysed in a single experiment.

The method is unlikely to provide information about an animal's population, but leeches should help to pin down its range. The
Vietnam field trial suggests that leeches preserve DNA from only their most recent blood meal, so an animal's range is likely to include the location where the leech was found.

Surveying leech blood is just one of many ways to collect environmental DNA that have emerged in recent years. In the Molecular Ecology special issue, various research teams worked out the diet of a leopard by sequencing DNA in its faeces ${ }^{3}$; tracked earthworm communities in soil ${ }^{4}$; and reconstructed ancient Siberian habitats from DNA preserved in permafrost ${ }^{5}$. Meanwhile, Australian scientists have found DNA from critically endangered species and potentially toxic plants in traditional Chinese medicines ${ }^{6}$.

Most of these studies are one-offs that show the potential of the techniques but not how points out Mehrdad Hajibabaei, an evolutionary molecular geneticist at the University of Guelph in Ontario, Canada. Even so, he says, assessments of environmental DNA have matched up well against more conventional surveys.

His team found that DNA surveys of water samples from a Canadian river identified the same invertebrate species as visual surveys ${ }^{7}$. And studies of plant DNA in soil from French to apply them to routine biodiversity surveys,
Alpine meadows and a tropical rainforest in French Guiana agreed well with ground-based vegetation studies ${ }^{8}$.

Researchers refer to environmental DNA studies as 'meta-bar-coding', because they rely on DNA bar codes: short DNA sequences that uniquely identify a species. Bar-coding makes it possible to distinguish between two species of butterfly, for example, by sequencing just a portion of a gene. But much of the DNA recovered from environmental sources such as soil or faeces has been shredded into short strands, and existing bar-coding databases tend to contain the longer stretches that were identified with old DNA sequencing technologies. Many of today's next-generation sequencers can read stretches of DNA that are shorter than the length of a bar code. "It's a shame that we cannot use all that has been developed," says Taberlet.

Hajibabaei, an adviser to the International the Barcode of Life project, which collates bar codes in to a publicly accessible library, responds that shorter, 'mini' bar codes, as well as advances in DNA sequencing technology, will address this problem.

In Vientiane last month, leeches were the talk of the IUCN's Saola Working Group meeting. Wilkinson says that the group hopes to offer rewards to villagers who bring in leeches with saola DNA, and to conduct targeted surveys led by scientists and park rangers. Wilkinson and his colleagues at the WWF plan to gather leeches from the Vietnamese side of the Annamites, and the Wildlife Conservation Society in New York intends to include leeches in its upcoming surveys of Laos.

"Everyone is, unsurprisingly, very excited about the potential," Wilkinson says. "We haven't detected a saola yet, but it's a very promising method for finding it and pretty much any other mammal in the forest." - SEE EDITORIAL P.416

1. Van Dung, V. et al. Nature 363, 443-445 (1993)

2. Schnell, I. B. et al. Curr. Biol. 22, R262-R263 (2012)

3. Shehzad, W. et al. Mol. Ecol. 21, 1951-1965 (2012)

4. Bienert, F. et al. Mol. Ecol. 21, 2017-2030 (2012).

5. Jørgensen, T. et al. Mol. Ecol. 21, 1989-2003 (2012).

6. Coghlan, M. L. et al. PLoS Genet. 8, e1002657 (2012).

7. Hajibabaei, M., Shokralla, S., Zhou, X., Singer, G. A. S. \& Baird, D. J. PLoS ONE 6, e17497 (2011).

8. Yoccoz, N. G. et al. Mol. Ecol. advance online publication http://dx.doi.org/10.1111/j.1365294X.2012.05545.x (2012).
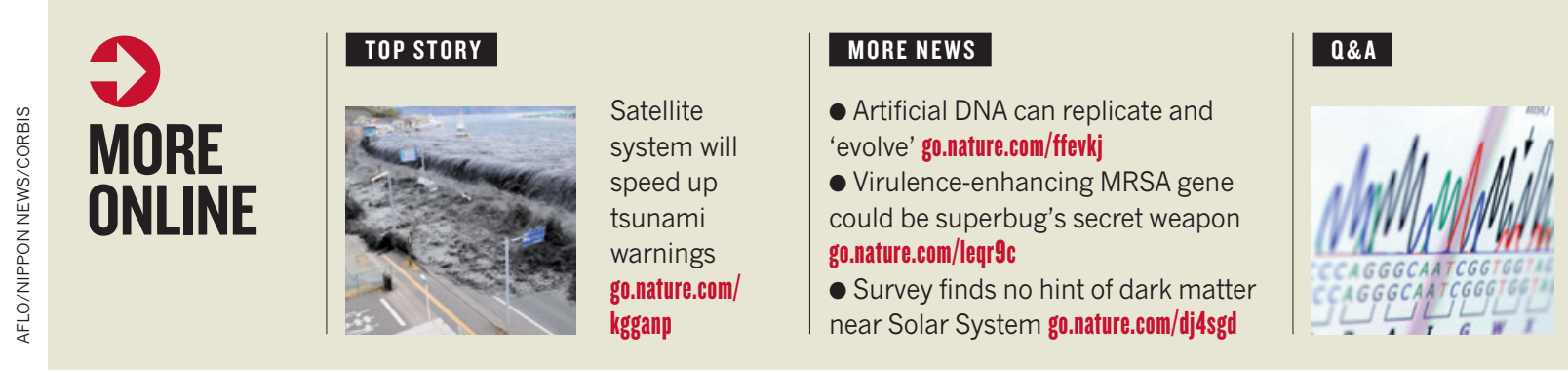

Next-
generation
DNA
sequencers
compared
go.nature.
com/5ra5c7

